\title{
PENGARUH MODEL PEMBELAJARAN BERPIKIR INDUKTIF TERHADAP HASIL BELAJAR
}

\section{Tiara Mahdalena Arwira, Asiah Ramadhani, dan Fauziah Nasution Surel: tiaramahdalenaarwira@gmail.com}

\begin{abstract}
Abstrak
Penelitian bertujuan untuk mengetahui pengaruh model pembelajaran berpikir induktif dan model konvensional terhadap hasil belajar siswa pada materi optika geometris kelas X di SMA Swasta Cerdas Murni Tembung. Jenis penelitian adalah quasi eksperiment dengan desain two group pretest posttest. Populasi dalam penelitian adalah seluruh siswa-siswi kelas X yang terdiri dari 2 kelas. Pengambilan sampel dilakukan dengan cara cluster random sampling. Sampel yang dipilih adalah kelas X-2 sebagai kelas eksperimen dengan model pembelajaran berpikir induktif yang berjumlah 30 orang dan kelas X-3 sebagai kelas kontrol dengan model pembelajaran konvensional yang berjumlah 30 orang. Instrumen yang digunakan dalam penelitian adalah tes pilihan berganda sebanyak 20 soal dengan 5 pilihan jawaban yang telah divalidkan oleh validator, observasi aktivitas belajar, sikap dan keterampilan siswa berupa lembar penilaian yang digunakan oleh observer. Statistik yang digunakan untuk pengujian hipotesis penelitian adalah uji t. Hasil uji t satu pihak diperoleh thitung $>$ tabel yaitu $(5,008>1,59)$, artinya ada pengaruh yang signifikan dalam penggunaan model pembelajaran berpikir induktif terhadap hasil belajar siswa pada materi optika geometris kelas X di SMA Swasta Cerdas Murni Tembung. Rata-rata nilai keseluruhan aktivitas siswa kelas eksperimen adalah 77,34 termasuk dalam kriteria aktif.
\end{abstract}

Kata Kunci: quasi eksperiment, berpikir induktif, hasil belajar

\section{PENDAHULUAN}

Menteri Pendidikan dan Kebudayaan (Mendikbud) menyatakan bahwa nilai rata-rata UN 2016 tingkat SMA/MA negeri dan swasta mengalami penurunan dari 61,29 (2014/2015) menjadi 54,78 (2015/2016). Dengan demikian, terjadi penurunan 6,51 angka jika dibandingkan nilai rata-rata UN tahun sebelumnya. Hal ini menunjukkan taraf pendidikan SMA/MA di Indonesia masih rendah dengan menurunnya hasil belajar siswa, terutama pada pelajaran fisika. Berdasarkan hasil wawancara dengan guru bidang studi fisika di SMA Swasta Cerdas Murni Tembung diperoleh data bahwa: (1) Kriteria Ketuntasan Minimal (KKM) adalah 75 (2) siswa jarang melakukan eksperimen, (3) nilai rata-rata hasil ujian siswa 60 terlihat bahwa hasil belajar masih rendah. Berdasarkan hasil angket yang disebarkan pada 30 siswa di kelas X SMA Swasta Cerdas Murni Tembung diperoleh hasil bahwa $76,7 \%$ siswa menyatakan untuk mengumpulkan data dan

\footnotetext{
Prodi Pendidikan Dasar PASCASARJANA UNIMED

Prodi Pendidikan Dasar PASCASARJANA UNIMED

Prodi Pendidikan Dasar PASCASARJANA UNIMED
} 
menyajikan data diperlukan mengumpulkan data tetapi $40 \%$ siswa tidak dapat memberikan contohnya, dari 30\% siswa menyatakan dapat menyajikan data dalam wacana fisika tetapi 93,3\% siswa menyatakan tidak dapat memberikan contohnya, dari $30 \%$ siswa menyatakan untuk menguji dan menghitung data diperlukan analisis tetapi $66,7 \%$ siswa menyatakan tidak mengetahui bagaimana cara menganalisis, dari $53,5 \%$ siswa menyatakan mengetahui pengertian hipotesis tetapi $86,7 \%$ siswa menyatakan tidak mengetahui contohnya dan $43,3 \%$ siswa menyatakan tidak pernah melakukan hipotesis.

Berdasarkan uraian di atas masalah yang diperoleh adalah hasil belajar siswa di bawah KKM, siswa jarang melakukan eksperimen, kemampuan mengumpulkan data masih rendah, kemampuan menyajikan data masih rendah, kemampuan menganalisis masih rendah dan kemampuan berhipotesis juga masih rendah. Berhubungan dengan masalah tersebut maka dipilih model pembelajran berpikir induktif. Karakteristik dari model pembelajaran berpikir induktif antara lain yaitu mampu membangun konsep siswa dengan cara menggeneralisasi, mengembangkan sikap positif terhadap objek, dan menekankan adanya partisipasi siswa dalam melakukan observasi, pengamatan, dan siswa diberi kesempatan secara maksimal untuk aktif dalam pembelajaran. Joyce (2009) menyatakan bahwa model berpikir induktif dikembangkan untuk bagaimanapun, dalam hal mengembangkan kapasitas berpikir, siswa perlu dituntut untuk mencerna dan memproses berbagai informasi. Model pembelajaran berpikir induktif memiliki empat tahap pembelajaran yaitu : (1) Mengidentifikasi dan menghitung data yang relevan dengan topik atau masalah, (2) Mengelompokkan objek-objek ini menjadi kategori-kategori yang anggotanya memiliki sifat umum, (3) Menafsirkan data dan mengembangkan label untuk kategori-kategori tadi sehingga data tersebut bisa dimanipulasi secara simbolis, dan (4) Mengubah kategori-kategori menjadi keterampilan atau hipotesis-hipotesis.

Joyce (2009) penerapan utama dari model pembelajaran berpikir induktif adalah mengembangkan kapasitas berpikir, bagaimanapun dalam hal mengembangkan kapasitas berpikir, siswa perlu dituntut untuk mencerna dan memproses berbagai informasi. Penerapan model pembelajaran berpikir induktif ini sudah pernah diteliti oleh beberapa peneliti sebelumnya seperti Putri (2014) berpendapat bahwa dari hasil penelitian diketahui model pembelajaran berpikir induktif berpengaruh secara signifikan terhadap hasil belajar siswa, Listyaningrum, (2012) berpendapat bahwa dari hasil penelitian diketahui model pembelajaran berpikir induktif dapat meningkatkan kualitas pembelajaran meliputi : kemanfaatan fasilitas pembelajaran, performance guru, iklim kelas, sikap ilmiah, dan motivasi berprestasi siswa dapat dilihat melalui hasil lembar

observasi, angket serta wawancara dengan guru dan siswa. Berorientasi pada model pembelajaran berpikir induktif yang didukung oleh Putri,dkk dan Listyaningrum,dkk peneliti akan melakukan pendataan kuantitas dari 
peningkatan hasil belajar siswa dengan melakukan pembentukan konsep, diskusi, melakukan percobaan, merumuskan hipotesis dan mempresentasikan hasil karya.

\section{METODE PENELITIAN}

Penelitian ini dilaksanakan di SMA Swasta Cerdas Murni Tembung. Waktu penelitian dilaksanakan pada bulan Januari 2017 di kelas X.

Populasi dalam penelitian ini adalah seluruh siswa kelas X SMA Swasta Cerdas Murni Tembung yang berjumlah 3 kelas. Dengan menggunakan teknik cluster random sampling, diperoleh sampel dari populasi sebanyak 2 kelas. Kelas eksperimen adalah kelas X-2 yang diberi perlakuan menggunakan model pembelajaran inductive thinking dan sebagai kelas kontrol adalah kelas X-3 yang dibelajarkan menggunakan pembelajaran konvensional. Penelitian ini melibatkan dua kelas yang diberikan perlakuan yang berbeda, untuk mengetahui hasil belajar siswa dilakukan dengan memberikan tes pada kedua kelas sebelum dan sesudah diberi perlakuan. Rancangan penelitian quasi eksperimen ini dengan desain : control group pretes - postes design. Adapun rancangan penelitian ini adalah seperti ditunjukkan pada tabel

\begin{tabular}{|l|l|l|l|}
\hline Kelas & $\begin{array}{l}\text { Pre- } \\
\text { tes }\end{array}$ & $\begin{array}{l}\text { Perla- } \\
\text { kuan }\end{array}$ & $\begin{array}{l}\text { Pos- } \\
\text { tes }\end{array}$ \\
\hline $\begin{array}{l}\text { Esperimen } \\
\text { Kontrol }\end{array}$ & $\mathrm{T}$ & $\mathrm{X}$ & $\mathrm{T}$ \\
$\mathrm{T}$ & - & $\mathrm{T}$ \\
\hline
\end{tabular}

Tabel Desain Penelitian Tipe Two Group (Pre-test dan Post-test)

Keterangan :

$\mathrm{X}=$ Pembelajaran dengan menggunakan model pembelajaran inductive thinking.

$\mathrm{Y}=$ Tidak ada perlakuan.

$\mathrm{T}=$ Pretes dan postes diberikan pada kelas eksperimen dan kelas kontrol. Instrumen yang digunakan dalam penelitian ini adalah tes hasil belajar siswa dalam bentuk pilihan berganda yang berjumlah 20 soal yang telah divalidkan oleh validator. Dan instrumen lembar observasi aktivitas, sikap dan keterampilan belajar siswa yang sesuai dengan pedoman buku KTSP 2006 yang berisi daftar jenis kegiatan yang mungkin timbul dan akan diamati. 


\section{HASIL PENELITIAN DAN PEMBAHASAN}

Adapun hasil pretes dari kedua kelas sebelum diberi perlakuan pada kelas eksperimen ditunjukkan pada Tabel

\begin{tabular}{|c|c|c|c|c|}
\hline \multirow[t]{2}{*}{ No. } & \multicolumn{2}{|c|}{$\begin{array}{l}\text { Kelas } \\
\text { Eksperimen }\end{array}$} & \multicolumn{2}{|c|}{$\begin{array}{l}\text { Kelas } \\
\text { Kontrol }\end{array}$} \\
\hline & Nilai & $\mathbf{F}$ & Nilai & $\mathbf{F}$ \\
\hline 1. & $9-15$ & 3 & $9-15$ & 5 \\
\hline 2. & $16-22$ & 5 & $16-22$ & 6 \\
\hline 3. & $23-29$ & 6 & $23-29$ & 6 \\
\hline 4. & $30-36$ & 7 & $30-36$ & 9 \\
\hline 5. & $37-43$ & 5 & $37-43$ & 2 \\
\hline \multirow[t]{2}{*}{6.} & $44-50$ & 4 & $44-50$ & 2 \\
\hline & \multicolumn{2}{|l|}{30,2} & \multicolumn{2}{|l|}{26,8} \\
\hline SD & \multicolumn{2}{|l|}{10,71} & \multicolumn{2}{|l|}{9,87} \\
\hline
\end{tabular}

Tabel Hasil Pretes Kelas Eksperimen dan Kelas Kontrol

Kemudian Data pretes dilakukan uji normalitas menggunakan uji Liliefors dan uji homogenitas menggunakan uji varians. Ringkasan uji normalitas dan homogenitas data pretes kelas eksperimen dan kontrol ditunjukkan pada Tabel.

\begin{tabular}{|c|c|c|c|c|c|c|}
\hline \multirow{2}{*}{ Kelas } & \multicolumn{2}{|c|}{ Data Pretes } & \multirow{2}{*}{$\begin{array}{c}\text { Kesim } \\
\text { pulan }\end{array}$} & \multicolumn{2}{|c|}{$\begin{array}{c}\text { Data } \\
\text { Pretes }\end{array}$} & $\begin{array}{c}\text { Kesim } \\
\text { pulan }\end{array}$ \\
\cline { 2 - 4 } & Fhit & Fta & \\
ung & $\begin{array}{r}\text { Lta } \\
\text { bel }\end{array}$ & & \\
\hline Ekperimen & 0,1546 & 0,1 & Normal & & 1,8 & Homo \\
& & 61 & Normal & & 6 & gen \\
\hline Kontrol & 0,1412 & & & & \\
\hline
\end{tabular}

Tabel Ringkasan uji normalitas dan homogenitas

Kemudian dilakukan uji hipotesis dua pihak (uji-t dua pihak) yang hasilnya disajikan dalam tabel.

\begin{tabular}{|c|c|c|c|}
\hline Kelas & $\begin{array}{l}\text { thitun } \\
\mathrm{g}\end{array}$ & ttabel & $\begin{array}{l}\text { Kesimpul } \\
\text { an }\end{array}$ \\
\hline $\begin{array}{l}\text { Ekspe } \\
\text { rimen }\end{array}$ & \multirow[b]{2}{*}{1,27} & \multirow{2}{*}{$\begin{array}{l}2,00 \\
2\end{array}$} & \multirow{2}{*}{$\begin{array}{l}\text { Kemampu } \\
\text { an Awal } \\
\text { Sama }\end{array}$} \\
\hline $\begin{array}{l}\text { Kontr } \\
\text { ol }\end{array}$ & & & \\
\hline
\end{tabular}

Tabel Uji Kemampuan Awal Siswa 
Kedua sampel kelas diberi perlakuan berbeda, setelah itu kedua kelas diberi postes. Adapun hasil postes dari kedua kelas dapat dilihat pada Tabel

\begin{tabular}{|c|c|c|c|c|}
\hline \multirow[t]{2}{*}{ No } & \multicolumn{2}{|c|}{$\begin{array}{l}\text { Kelas } \\
\text { Eksperimen }\end{array}$} & \multicolumn{2}{|c|}{$\begin{array}{l}\text { Kelas } \\
\text { Kontrol }\end{array}$} \\
\hline & Nilai & f & Nilai & $\mathbf{F}$ \\
\hline 1 & $55-60$ & 3 & $43-48$ & 3 \\
\hline 2 & $61-66$ & 3 & $49-54$ & 4 \\
\hline 3 & $67-72$ & 4 & $55-60$ & 6 \\
\hline 4 & $73-78$ & 8 & $61-66$ & 7 \\
\hline 5 & $79-84$ & 7 & $67-72$ & 5 \\
\hline \multirow[t]{3}{*}{6} & $85-90$ & 5 & $73-78$ & 4 \\
\hline & & & $79-84$ & 1 \\
\hline & \multicolumn{2}{|l|}{74,7} & \multicolumn{2}{|l|}{62,2} \\
\hline SD & \multicolumn{2}{|l|}{9} & \multicolumn{2}{|l|}{10,15} \\
\hline
\end{tabular}

Tabel Data Postes Hasil Belajar

Selanjutnya data postes juga dilakukan uji normalitas menggunakan uji Liliefors dan uji homogenitas menggunakan uji varians. Ringkasan uji normalitas dan homogenitas data postes kelas eksperimen dan kontrol ditunjukkan pada Tabel .

\begin{tabular}{|c|c|c|c|c|c|c|}
\hline \multirow[b]{2}{*}{ Kelas } & \multicolumn{2}{|c|}{$\begin{array}{l}\text { Data } \\
\text { Postes }\end{array}$} & \multirow{2}{*}{$\begin{array}{l}\text { Kes } \\
\text { imp } \\
\text { ula } \\
\text { n }\end{array}$} & \multicolumn{2}{|c|}{$\begin{array}{l}\text { Data } \\
\text { Postes }\end{array}$} & \multirow[t]{2}{*}{ Kesimpulan } \\
\hline & $\begin{array}{l}\text { Lh } \\
\text { itun } \\
\text { g }\end{array}$ & $\begin{array}{l}\text { Lta } \\
\text { bel }\end{array}$ & & $\begin{array}{l}\text { Fhi }_{\text {hi }} \\
\text { tun } \\
\text { g }\end{array}$ & $\begin{array}{l}F_{t} \\
\text { ab } \\
\text { el }\end{array}$ & \\
\hline Ekperimen & $\begin{array}{l}0, \\
11 \\
09\end{array}$ & \multirow{2}{*}{$\begin{array}{l}0,1 \\
61\end{array}$} & $\begin{array}{l}\text { Nor } \\
\text { mal }\end{array}$ & \multirow{2}{*}{$\begin{array}{l}1,2 \\
7\end{array}$} & \multirow{2}{*}{$\begin{array}{l}1, \\
8 \\
6\end{array}$} & \multirow{2}{*}{ Homo gen } \\
\hline Kontrol & $\begin{array}{l}0, \\
11 \\
82\end{array}$ & & $\begin{array}{l}\text { Nor } \\
\text { mal }\end{array}$ & & & \\
\hline
\end{tabular}

Tabel Ringkasan hasil perhitungan uji normalitas dan homogenitas data postes kelas eksperimen dan kontrol

Pengujian hipotesis dengan uji t pada postes yaitu membedakan rata-rata hasil postes siswa pada kelas eksperimen dan kelas kontrol dengan tujuan untuk mengetahui ada tidaknya pengaruh model berpikir induktif terhadap hasil belajar siswa pada materi pokok optika geometris. Hasil uji t postes dapat dilihat pada tabel. 


\begin{tabular}{|c|c|c|c|}
\hline Kelas & thitung & ttabel & $\begin{array}{l}\text { Kesimp } \\
\text { ulan }\end{array}$ \\
\hline Eksperimen & & & $\mathrm{Ha}$ \\
\hline Kontrol & 5,008 & 1,59 & $\begin{array}{l}\text { diterima, } \\
\text { Ada } \\
\text { pengaruh }\end{array}$ \\
\hline
\end{tabular}

Tabel Data Uji t Satu Pihak

Berdasarkan tabel diatas diperoleh thitung $>$ tabel dengan taraf signifikan 0,05 dan $\mathrm{dk}=58$ maka $\mathrm{Ha}$ diterima dan $\mathrm{H}_{0}$ ditolak. Dapat disimpulkan bahwa ada pengaruh model pembelajaran berpikir induktif terhadap hasil belajar siswa pada materi pokok optika geometris.

Pada saat pembelajaran berlangsung peneliti dan observer mengamati perilaku siswa sesuai kebutuhan berdasarkan indikator pada lembar observasi penilaian sikap siswa. Penilaian sikap siswa dapat dilihat pada tabel .

\begin{tabular}{|l|l|l|l|}
\hline \multirow{2}{*}{ No } & $\begin{array}{l}\text { Pert } \\
\text { emu } \\
\text { an } \\
\text { Ke- }\end{array}$ & \begin{tabular}{l} 
Kelas eksperimen \\
\cline { 3 - 4 } \\
rata \\
Sikap
\end{tabular} & Kriteria \\
\hline 1. & I & 69,17 & $\begin{array}{l}\text { Cukup } \\
\text { Baik }\end{array}$ \\
\hline 2. & II & 80 & Baik \\
\hline 3. & III & 83,16 & Baik \\
\hline \multicolumn{2}{|l}{ Rata-Rata } & $\mathbf{7 7 , 4 4}$ & Baik \\
\hline
\end{tabular}

Tabel Hasil observasi sikap dan keterampilan siswa

Aktivitas belajar siswa diamati selama tiga kali pertemuan dan nilai aktivitas belajar siswa diambil dari rata-rata aktivitas selama tiga kali pertemuan. Untuk melihat lebih rinci data pretes, aktivitas dan data posttes dapat dilihat pada Gambar . 


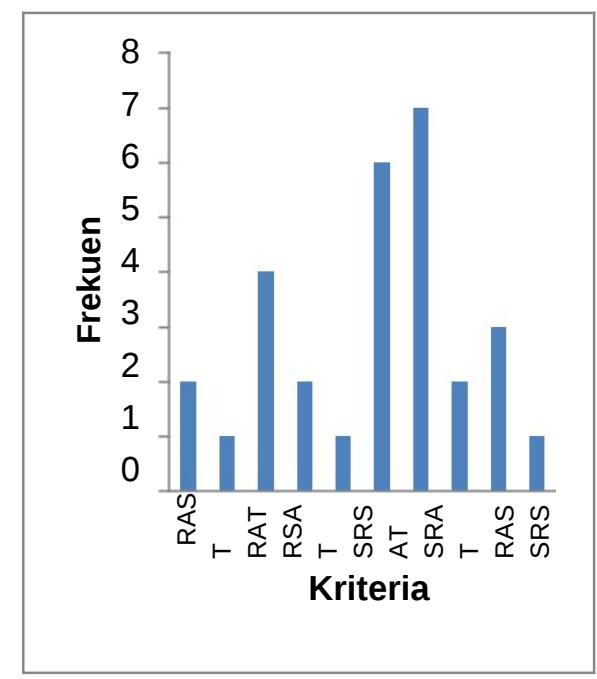

Gambar . Diagram Batang Kategori Pencapaian Siswa Mulai Dari pretest, Aktivitas Hingga Posttest

\section{Keterangan :}

SRAR : Sangat Rendah, Aktif, Rendah

RSAR : Rendah, Sangat Aktif, Rendah

SRAS : Sangat Rendah, Aktif, Sedang

SRSAS: Sangat Rendah, Sangat Aktif, Sedang

RAS : Rendah, Aktif, Sedang

SRAT : Sangat Rendah, Aktif, Tinggi

SRSAT: Sangat Rendah, Sangat Aktif, Tinggi

RSAT: Rendah, Sangat Aktif, Tinggi

RAT : Rendah, Aktif, Tinggi

RAST :Rendah, Aktif, Sangat Tinggi

Berdasarkan gambar 1, terdapat 2 siswa $(6,67 \%)$ memiliki kategori SRAR, 1 siswa (3,33\%) memiliki kategori RSAR, 4 siswa (13,33\%) memiliki kategori SRAS, 2 siswa (6,67\%) memiliki kategori SRSAS, 1 siswa (3,33\%) memiliki kategori RAS, 6 siswa (20\%) memiliki kategori SRAT, 7 siswa $(23,33 \%)$ memiliki kategori SRSAT, 2 siswa (6,67\%) memiliki kategori RSAT, 3 siswa (10\%) memiliki kategori RAT, 1 siswa memeiliki (3,33\%) kategori RAST.

Berikut ini ditampilkan grafik nilai pretes, nilai aktivitas dan nilai posttest siswa kelas eksperimen yang disusun berdasarkan kategori yang paling rendah sampai yang paling tinggi. 


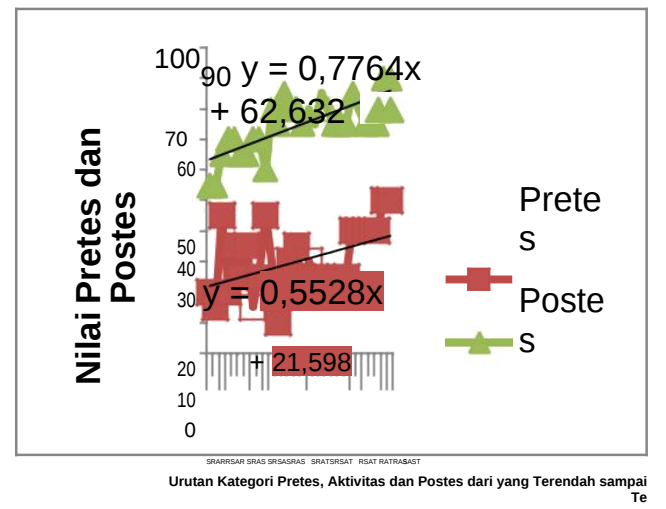

Grafik Hubungan Antara Nilai Pretes, Nilai Aktivitas dan Nilai Postest Pada Kelas Eksperimen Berdasarkan Kategori Aktivitas

Pada Grafik diatas diperoleh dengan menggunakan program Microsoft Office Excel 2010. Persamaan linier y $=\mathrm{ax}+\mathrm{b}$ memiliki nilai a yang menyatakan kemiringan garis. Jika dilihat dari grafik, nilai a pada ypost $=0,7764 \mathrm{x}+62,632$ lebih besar dibandingkan dengan nilai a pada ypre $=0,5528 x+21,598$. Nilai a pada persamaan linier pretes (apre) menjadi acuan kriteria dalam menentukan berpengaruh atau tidaknya nilai aktivitas.

Adapun kriterianya adalah sebagai berikut :

apost $>$ apre $\quad$ : nilai aktivitas mempengaruhi hasil belajar (nilai postes)

apost $<$ apre : nilai aktivitas tidak mempengaruhi hasil belajar (nilai postes) Pada grafik diatas menunjukkan apost $>$ apre meskipun perbedaan nilai apost

dan apre sangat kecil, yang berarti nilai aktivitas mempengaruhi hasil belajar (nilai postes).

Berikut ini ditampilkan grafik hubungan antara nilai pretes, nilai aktivitas dan nilai postes siswa pada kelas eksperimen yang disusun berdasarkan nilai aktivitas terendah ke nilai aktivitas tertinggi.

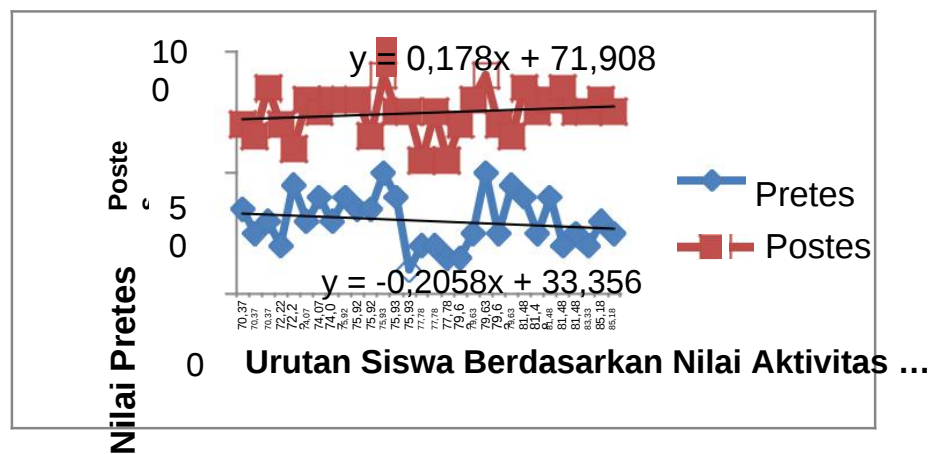

Grafik Nilai Pretes, Aktivitas dan Postest Berdasarkan Nilai Aktivitas Terendah Sampai Tertinggi Secara Induvidu

Dari grafik diperoleh dengan menggunakan program Microsoft Excel 2010. Persamaan linier $\mathrm{y}=\mathrm{ax}+\mathrm{b}$ memiliki nilai a yang menyatakan kemiringan garis. Jika dilihat dari grafik, nilai a pada ypost $=0,178 x+71,908$ lebih besar dibandingkan dengan nilai a pada ypre $=-0,2058+33,356$. Hal ini menunjukkan 
ISBN: 978-602-50622-0-9 
apost $>$ apre meskipun perbedaan nilai apre dan apost sangat kecil, yang berarti nilai aktivitas mempengaruhi hasil belajar (nilai postes) secara individu.

Data nilai siswa secara perkelompok dapat disusun berdasarkan urutan nilai rata-rata perkelompok dari urutan nilai rata-rata aktivitas terendah ke nilai rata-rata aktivitas tertinggi. Secara lebih rinci data tersebut ditampilkan dalam gambar berikut.

Grafik Nilai Pretes, Aktivitas

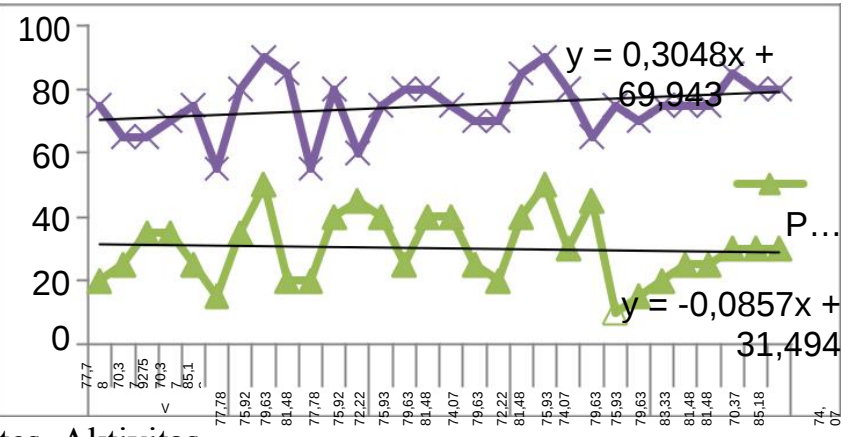

dan Postest Berdasarkan Nilai Aktivitas Terendah

Sampai Tertinggi Secara Kelompok

Dari grafik diperoleh dengan menggunakan program Microsoft Excel 2010. Persamaan linier $\mathrm{y}=\mathrm{ax}+\mathrm{b}$ memiliki nilai a yang menyatakan kemiringan garis. Jika dilihat dari grafik, pada ypost $=0,3048 x+69,943$ memiliki nilai a yang lebih besar dibandingkan dengan nilai a pada ypre $=-0,0857 x+31,494$. Hal ini berarti apost $>$ apre meskipun perbandingan nilai apost dan apre sangat kecil, yang berarti nilai aktivitas mempengaruhi hasil belajar (nilai postes) secara kelompok.

Grafik - grafik diatas merupakan nilai grafik nilai aktivitas siswa dalam proses, individu dan kelompok yang diurutkan dari nilai terendah ke tertinggi yang masing-masing memiliki persamaan linier, karena nilai apost dan apre sangat kecil, maka dapat disimpulkan bahwa aktivitas mempengaruhi hasil belajar siswa namun pelaksanaan model berpikir induktif dalam penelitian ini kurang maksimal. Hal ini disebabkan karena segi perencanaan dan manajemen waktu kurang baik serta pembagian kelompok yang kurang heterogen. Maka dari itu perlu dilakukan perbaikan baik dari segi perencanaan maupun segi pelaksanaan.

\section{SIMPULAN}

Berdasarkan hasil penelitian yang diperoleh dari hasil analisa data dan pengujian hipotesis maka dapat disimpulkan sebagai berikut:

Hasil belajar siswa kelas X di SMA Swasta Cerdas Murni Tembung dengan menggunakan model pembelajaran berpikir induktif dinyatakan tuntas KKM dengan nilai KKM 75 dimana nilai rata-rata yang diperoleh sebesar 74,7 dengan rincian tuntas KKM berjumlah 20 orang dengan tingkat kriteria kemampuan sedang.

Hasil belajar siswa kelas X di SMA Swasta Cerdas Murni Tembung dengan menggunakan pembelajaran konvensional dinyatakan tidak tuntas KKM 
dengan nilai KKM 75 dimana nilai rata-rata kelas yang diperoleh sebesar 62,2 dengan rincian tuntas KKM berjumlah 5 orang dengan tingkat kemampuan rendah.

Ada pengaruh model pembelajaran berpikir induktif terhadap hasil belajar siswa pada materi optika geometris kelas X di SMA Swasta Cerdas Murni Tembung, berdasarkan analisis uji hipotesis diperoleh thitung $>$ ttabel $(5,008>$ $1,59)$.

Berdasarkan hasil penelitian dan kesimpulan dalam penelitian ini, maka peneliti mempunyai beberapa saran, yaitu:

Kepada guru ataupun calon guru yang ingin menggunakan model Berpikir Induktif hendaknya membuat deskriptor penilaian aktivitas yang lebih baik lagi dan disesuaikan dengan fase-fase siswa pada model ini dan lebih memperhatikan pembagian kelompok agar pembelajaran bisa berjalan lebih efektif.

Selalu memberikan inovasi dalam kegiatan pembelajaran yaitu dengan menciptakan suasana belajar yang menarik dan menyenangkan.

Bagi peneliti selanjutnya yang ingin meneliti menggunakan model pembelajaran berpikir induktif disarankan untuk memperhatikan efisiensi waktu terutama saat siswa melakukan eksperimen dan mengerjakan lembar kerja siswa sehingga semua sintaks efektif saat pelaksanaan proses pembelajaran.

\section{DAFTAR RUJUKAN}

Dahar, Ratna Wilis, (2011), Teori-Teori Belajar dan Pembelajaran. Jakarta:Erlangga .

Dimyati, Mudjiono, (2013), Belajar dan Pembelajaran. Jakarta: Rineka Cipta

Fakultas Matematika dan Ilmu Pengetahuan Alam Universitas Negeri Medan, (2012), Buku Pedoman Penulisan Proposal Skripsi Prodi Kependidikan. Fmipa, Unimed.

Istarani, (2012), 58 Model Pembelajaran Inovatif.Medan: Media Persada

Joyce, Bruce et all, (2009), Models Of Teaching: Model-Model Pengajaran, Pustaka Pelajar, Yogyakarta.

Kanginan, M., (2007), Fisika untuk SMA Kelas X Semester 2, Jakarta, Erlangga

Kementrian Pendidikan dan Kebudayaan Badan Penelitian dan Pengembengan Pusat Penilaian Pendidika, (2016), Laporan Hasil Ujian Nasional Tahun 2016, Balitbang, Kemdikbud

Listyaningrum, Ika Rahmawati dkk, (2012), Penerapan Model Pembelajaran Inductive Thinking Berbasis Keterampilan Proses Sains Untuk Meningkatkan Kualitas Pembelajaran Biologi Siswa Kelas X.7 SMA 
Negeri 2 Karanganyar Tahun Pelajaran 2011/2012, Jurnal Pendidikan Biologi, 4 (1), Hal. 56-67

Muhamad, P., (2014), Pengaruh Model Pembelajaran Berpikir Induktif Terhadap Hasil Belajar Fisika Siswa Pada Konsep Getaran dan Gelombang Skripsi, FITK, UIN Syarif Hidayatullah, Jakarta.

Purwanto, (2011), Evaluasi Hasil Belajar, Pustaka Pelajar, Yogyakarta.

Putri, Ida Ayu Adisti Ligianing dkk, (2014), Pengaruh Model Pembelajaran Induktif Berbasis Integratif Terhadap Hasil Belajar IPA Siswa kelas V Semester I Sekolah Dasar Gugus R. A. Kartini, Jurnal Mimbar PGSD Universitas Pendidikan Ganesha, 2(1), Hal. 1-11

Rusman, (2010), Model-Model Pembelajaran Mengembangkan Profesionalisme Guru Edisi Kedua, Rajawali Pers, Jakrta

Sani, Ridwan Abdullah, (2013), Inovasi Pembelajaran, Bumi Aksara, Jakarta.

Sanjaya, Wina, (2006), Strategi Pembelajaran Berorientasi Standar Proses Pendidikani, Kencana Prenada Media, Jakarta

Sardiman, (2011), Interaksi dan Motivasi Belajar Mengajar, Rajawali Press, Jakarta.

Slameto. (2010), Belajar dan Faktor-Faktor yang Mempengaruhinya, Rineka Cipta,. Jakarta.

Sudjana, (2005), Metoda Statistika, Tarsito, Bandung.

Sudjana, Djudju, (2006), Evaluasi Program Pendidikan Luar Sekolah, Remaja Rosdakarya, Bandung

Trianto, (2009), Mendesain Model Pembelajaran Inovatif-Progresif), Kencana, Jakarta. 